\title{
Living Spaces, Communal Places: Early Modern Jewish Homes and Religious Devotions
}

\author{
Debra Kaplan
}

In* the seventeenth century, Juspe Schammes, the sexton of the Worms synagogue, composed a book documenting the various customs of his community, including the details of the synagogue service. On the days when the Torah was read aloud in the synagogue, a set number of men from the community were individually called up by name. Once called up, the man would recite a blessing over the Torah, and remain present next to the Torah scroll at the centre of the synagogue as a section was read aloud. The custom book includes a section listing the occasions on which specific male members of the community were honoured with being called up to the Torah. Communal officials, for example, were honoured with being called to the Torah on particular dates, while other community members celebrating life-cycle events such as marriage or the anniversary of a close relative's death were called to the Torah on the relevant dates. Included in this list of honourees was a man who moved into a new house. ${ }^{1}$ This same practice was also observed in Frankfurt am Main, as is reported in the eighteenth-century custom book Minhag ka-tzon Yosef. The author records that: 'According to the custom in the holy community of Frankfurt, anyone who moves to a different house is obligated [to be called to the Torah] on the first Sabbath [after the move].' This honour may have had roots in the Bible, which exempted a man who had moved into a new home and had not yet dedicated it from serving as a soldier in wartime. ${ }^{3}$ Nevertheless, the early modern practice demonstrates that moving into a new home was actively considered a momentous event marked by a sacred ritual.

This ritual was a public performance that acknowledged a change in domestic life in the space of the larger community. It underscores that rather than constituting two discrete categories, domestic and communal places overlapped, with religious devotion playing a role in both. Being called to the Torah

\footnotetext{
* This research was supported by THE ISRAEL SCIENCE FOUNDATION (grant No. 1409/15).

1 Schammes J., Customs of the Holy Community of Worms, ed. B.S. Hamburger and E. Zimmer, 2 vols. (Jerusalem: 1988) vol. 1, no. 38 .

2 Kosman Joseph, Noheg ka-tzon Yosef (Hanau, Jacob Bassange: 1718) 138.

3 Deuteronomy 20:5.

(C) DEBRA KAPLAN, 2019 | DOI:10.1163/9789004375888_017

This is an open access chapter distributed under the terms of the prevailing CC-BY-NC-ND License
} at the time of publication. 
in the public space of the synagogue because one had moved into a new home bridged the space of home with the space of the community.

It is perhaps not at all surprising that the home was connected to both religion and to communal rituals among Jews in early modern Europe. After all, the home was not really a private place. In early modern Europe, for both Jews and Christians, the home was both a domicile as well as a place of work. As Lyndal Roper has demonstrated in her work on Protestant families, the ideal holy family represented a harmony of social, economic, and moral order in the space of the household workshop. ${ }^{4}$ If we consider that the space of the early modern home was multi-use - it was a space in which work and chores, religious practice, child rearing, and hospitality took place - we can more easily understand the deep connections between work, household duties, and religious devotion.

This article explores how Jews expressed religious devotion at home, in consideration of the various different uses of early modern homes. Rituals were performed in domestic spaces, both chores and work were sometimes infused with religious meaning and significance, and private and communal sacred space was sometimes designated within the home. The approach of looking at religious devotion through the lens of the domestic sphere enables us to see how intrinsic religious meaning was to a very broad set of behaviours, including mundane practices. Moreover, by examining the intersections between the home and religious devotion in its myriad forms, scholars are able to uncover the religious experiences of Jewish women and to understand the ways in which religious devotion was often gendered.

\section{1 Jewish Homes and Domestic Devotion}

Although Roper's work on the Protestant family serves as a model for studying religion, the domestic sphere and gender, there is an important distinction between early modern Protestant and Jewish practices. The connection between the Jewish home and the sacred is not at all surprising, given that

4 Roper L., The Holy Household: Women and Morals in Reformation Augsburg (Oxford: 1989) 252. See also Wunder H., He is the Sun: She is the Moon: Women in Early Modern Germany, trans. T. Dunlap (Cambridge, MA: 1998). This approach indicates that the distinction between public and private places was not as sharp in the early modern period. On this point see Ulbrich C., Shulamit and Margarete: Power, Gender, and Religion in a Rural Society in EighteenthCentury Europe, trans. T. Dunlap (Leiden: 2004) 4-14; Bock G., "Challenging Dichotomies: Perspectives on Women's History," in Offen K. - Pierson R.R. - Rendall J. (eds.), Writing Women's History: International Perspectives (London: 1991) 1-23. 


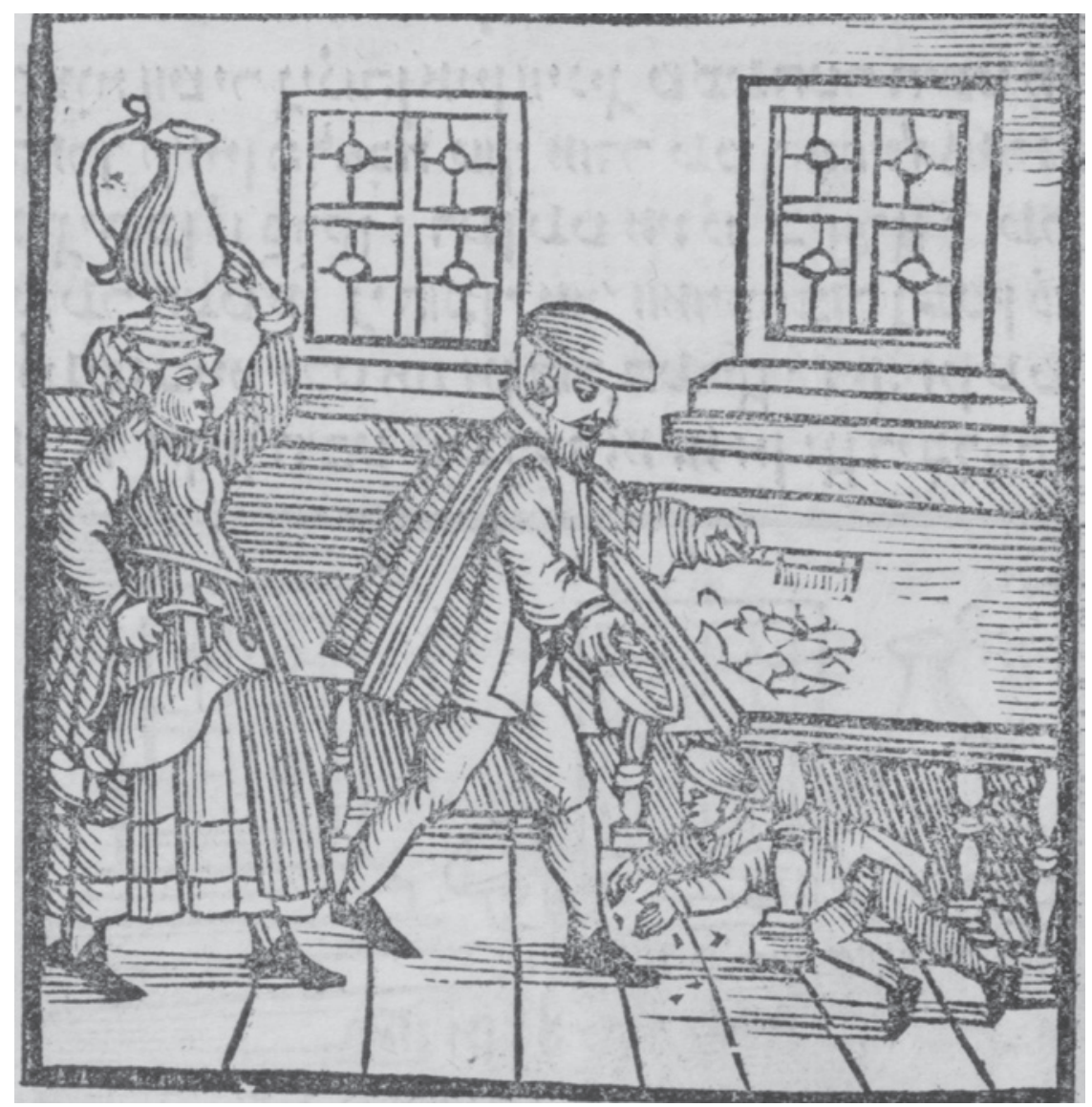

FIGURE 15.1 Book of Customs (Sefer Minhagim) (Venice, Giovanni di Gara: 1593). The Bodleian Libraries, The University of Oxford, Opp. $4^{\circ}$ 1006, fol. 19r. Cleaning the home for Passover

many daily Jewish commandments were designed to regulate domestic spaces. For example, Jewish dietary laws required the separation of milk and meat, and included food restrictions on Passover, which involved removing leavened products from the domestic sphere. In an Italian woodcut from 160o, various family members are depicted conducting the search for leavened grains on the eve of Passover in their home [Fig. 15.1]..$^{5}$ Such laws regulating food were all

5 On the 1593 customs book in which this illustration appears, see Feuchtwanger-Sarig N., "How Italian are the Venice 'Minhagim' of 1593? A Chapter in the History of Yiddish Printing in Italy", in Graetz M. (ed.), Schöpferische Momente des europäischen Judentums in der frühen Neuzeit (Hamburg: 2000) 177-205. 
practised in the home. In fact, rabbinic responsa dealt explicitly with Jewish law, food, and the home. In one example, the sixteenth-century Polish rabbi Benjamin Slonik was asked if it was permissible to soak and salt meat - a practice done to remove the blood from the meat, necessary to render the meat kosher - in the utensil of a non-Jew in a case in which when a Jew lodged in a non-Jew's home and had no kosher utensil. ${ }^{6}$ Here, being outside the space of one's home raised questions about how to perform a normative ritual practice - a fact that underscores the extent to which one's home, and its objects and cooking utensils were part and parcel of the observance of daily dietary commandments.

Both texts and illustrations printed in early modern custom books depict the centrality of the home as the locus in which certain rituals were performed. ${ }^{7}$ Woodcuts from sixteenth- and seventeenth-century Italian custom books, like the one mentioned above, portray various religious rituals in domestic spaces. These include, for example, a woman blessing Sabbath candles, a weekly ritual that marked the onset of the Sabbath on Friday evening [Fig. 15.2]. It is not incidental that women are present in these two images, and in others like them. Since they were often present and active in domestic spaces, they participated in rituals that took place in the home. It should be noted that in the two aforementioned images, the women were active participants. ${ }^{8}$ In other rituals, such as the havdalah ceremony, which marked the conclusion of the Sabbath, women were less active than their male counterparts. During the ceremony, biblical verses and blessings over wine, aromatic spices, and a candle forged of at least two wicks were recited. In this scene, as depicted in an Italian custom book from 1600 , the father holds the wine glass and recites the prayer, while his sons respectively hold the candle and the spice container. The mother of the family and one of the sons are lifting their hands to the light, as was customary during the ceremony [Fig. 15.3]. The two daughters, though present at the ritual, are depicted as passive participants.

While the aforementioned rituals were all performed at home by design, in pre-modern times, additional rituals were at times celebrated in the home

6 Slonik Benjamin, She'elot u-teshuvot masa'at Binyamin (Krakow, Meisels: 1632) no. 30.

7 On early modern custom books, see Baumgarten J., "Prayer, Ritual, and Practice in Ashkenazic Jewish Society: The Tradition of Yiddish Custom Books in the Fifteenth through Eighteenth Centuries", Studia Rosenthaliana 36 (2002-3) 121-46.

8 Other examples of active female participation in rituals in the home include birth and postpartum rituals. See Sabar S., "Childbirth and Magic: Jewish Folklore and Material Culture", in Biale D. (ed.), Cultures of the Jews: A New History (New York: 2002) 671-722. See specifically his discussion of the popular use of the Torah scroll. See also Baumgarten E., Mothers and Children:Jewish Family Life in Medieval Europe (Princeton: 2004) 99-116. 


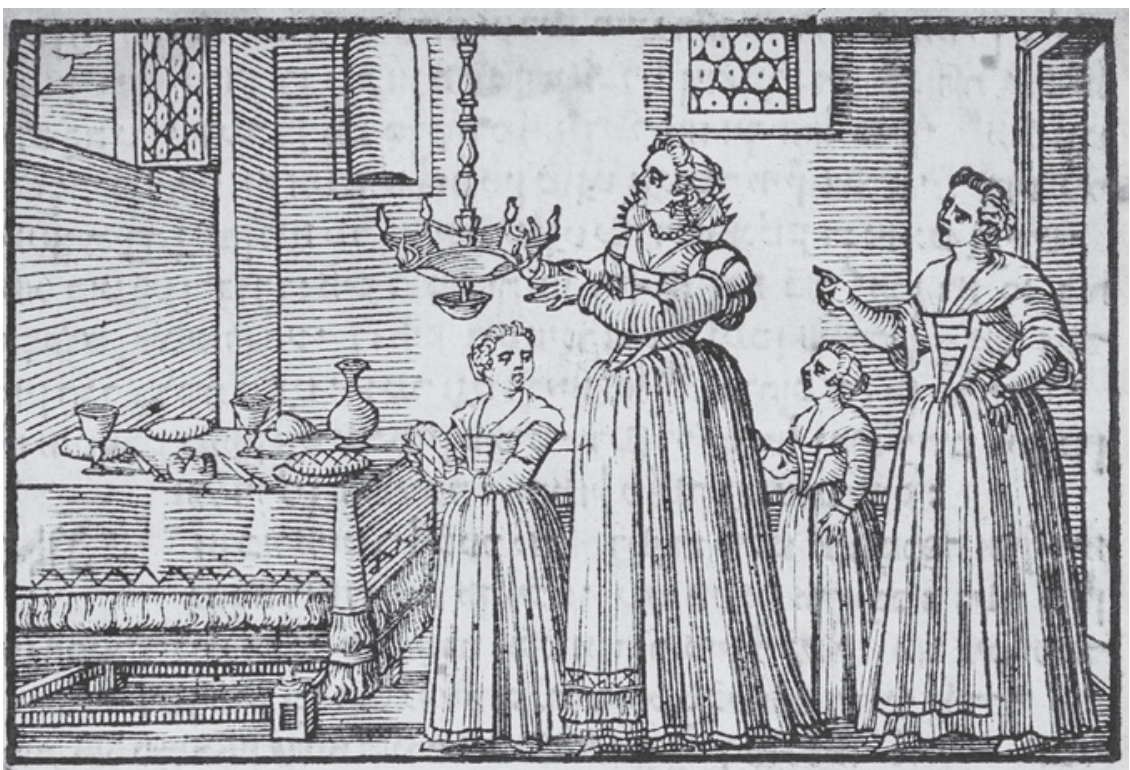

FIGURE 15.2 Book of Customs (Sefer Minhagim) (Venice, Giovanni di Gara: 16oo). The Bodleian Libraries, The University of Oxford, Opp. $4^{\circ}$ 1004, fol. 39v. Kindling Sabbath Candles

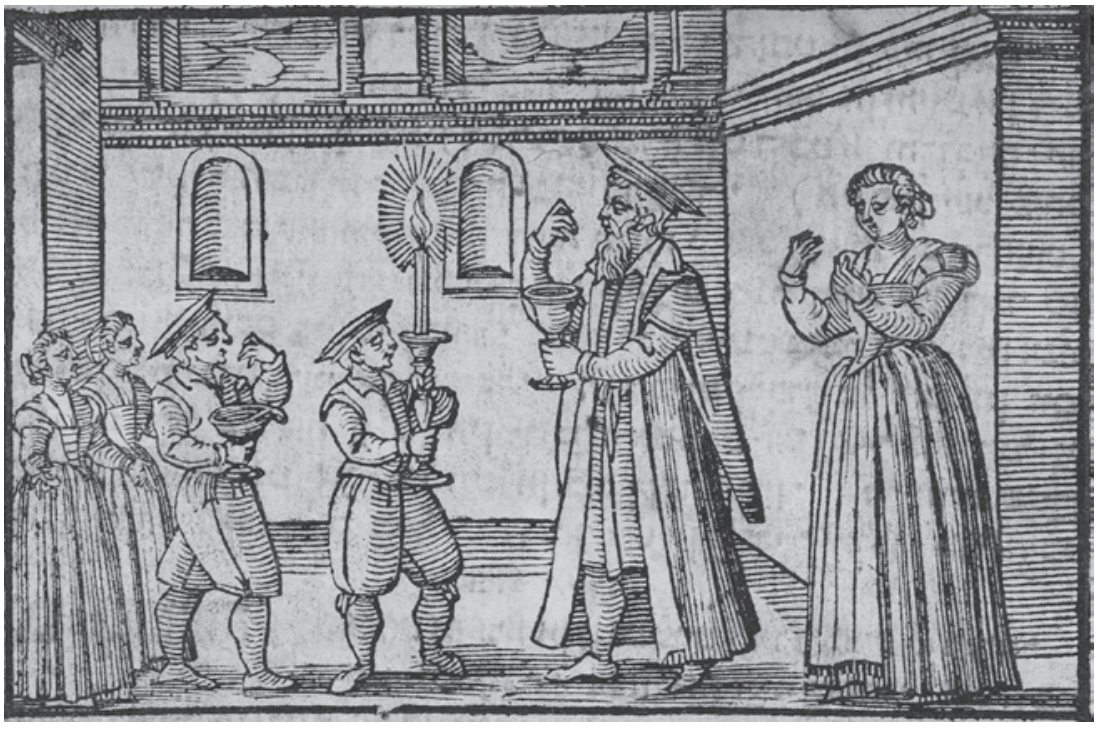

FIGURE 15.3 Book of Customs (Sefer Minhagim) (Venice, Giovanni di Gara: 160o).

The Bodleian Libraries, The University of Oxford, Opp. $4^{\circ}$ 1004, fol. $63 \mathrm{v}$. Havdalah ceremony at the conclusion of the Sabbath 


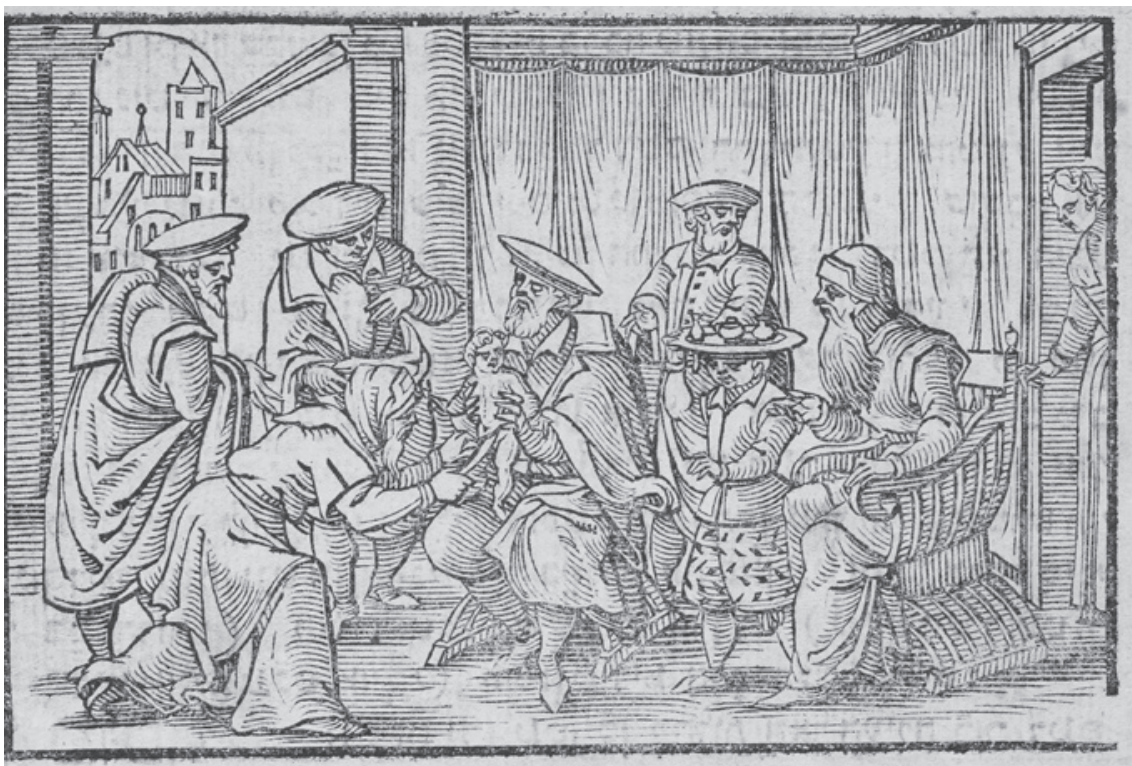

FIGURE 15.4 Book of Customs (Sefer Minhagim) (Venice, Giovanni di Gara: 16oo). The Bodleian Libraries, The University of Oxford, Opp. $4^{\circ}$ 1004, fol. gov. Circumcision

rather than in the synagogue. The circumcision ceremony, for example, was sometimes practised in the space of the home, as portrayed in the Italian custom book from $1600 .{ }^{9}$ Here too, a woman is present, albeit in a passive role [Fig. 15.4].

Considering the space of the home and the devotions that were performed there allows us to glimpse Jewish women's piety. Unlike Catholic women who could opt to become nuns or to serve as pious women in lay institutions, Jewish women, like their Protestant counterparts, were expected to marry, have children, and to experience fulfilment, religious and otherwise, in the role of mother and wife. ${ }^{10}$ Though women were often present in the synagogue, men played the central role in public rituals. The establishment of different norms for men and women also led to gendered forms of piety.

A comparison of men and women's charitable activities provides a vivid example. Both men and women were expected to donate to the poor, although Jewish scholars debated the degree of autonomy that married women had in

$9 \quad$ Baumgarten, Mothers and Children $55^{-89}$.

10 I am in no way suggesting that all Catholic women who entered the nunnery did so by choice. Jewish women, however, did not have any comparable option. 
donating from joint assets. ${ }^{11}$ Sources describe women as giving or collecting food items for the poor, whereas much of male charitable giving took place in the synagogue. ${ }^{2}$ While men donated to charity after being honoured as participants during the synagogue service, women tended to be involved in more intimate forms of feeding the poor. ${ }^{13}$ This included the system known as pletten, under which poor individuals drew lottery tickets assigning them to eat a meal in a particular household. Though each family was required to host the poor, the women were those most intimately involved with hospitality, cooking and feeding. ${ }^{14}$

The crypto-Jewish women of the Iberian Peninsula provide another example of women's participation in domestic devotion. ${ }^{15}$ After the establishment of the Inquisition in late fifteenth-century Spain, crypto-Jews, who were outwardly Christian but who observed Judaism in secret, only practised Judaism in domestic spaces where they could hide these practices. As Reneé LevineMelammed has shown, observance of Jewish tradition after that point includes preparing meat in a particular manner, lighting Sabbath candles, fasting, changing linen and washing oneself before the Sabbath. Moreover, once Jewish practice was confined to domestic spaces, women emerged as the leaders of crypto-Jewish communities, who passed on traditions to the next generation.

\section{The Home, Women's Work, and Devotion}

In the case of crypto-Judaism, religious practice was limited to domestic spaces, while in normative Jewish communities, religious practices took place both in the home and in communal spaces such as synagogues, hospices, and cemeteries. At the same time, the devotional aspects of the domestic activities

11 Gray A., "Married Women and Tsedaqah in Medieval Jewish Law: Gender and the Discourse of Legal Obligation", Jewish Law Association Studies 18 (2007) 168-212.

12 Chovav Y., Maidens Love Thee: The Religious and Spiritual Life of Jewish Ashkenazic Women in the Early Modern Period [Hebrew] (Jerusalem: 2009) 388.

13 Men donated to charity after having been honoured in the synagogue. The association between the home and women's charity is already referenced in the Talmud. See Babylonian Talmud Tractate Ta'anit 23b. Juspe Schammes borrows the Talmudic phrase when describing female charitable giving. See Schammes, Customs vol. 2, 145.

14 Berkovitz J.R., "Jewish Philanthropy in Early Modern and Modern Europe: Theory and Practice in Historical Perspective", in Prager Y. (ed.), Toward a Renewed Ethic of Jewish Philanthropy (New York: 2010) 98-99.

15 Levine-Melammed R., Heretics or Daughters of Israel? The Crypto-Jewish Women of Castile (Oxford: 2002). 
performed by crypto-Jews were also common in more normative Jewish communities, where household chores were often seen as having religious significance, particularly for women.

This perception is reflected in the sixteenth-century text, Meneket Rivka, the first Yiddish morality text written by a woman. Its author, Rivka Tiktiner, composed this treatise to preach proper behaviour to women. In it, she notes that, 'A woman should also be cautious with and pay attention to the cleanliness of her house, particularly where one prays, or religious books are, or near the mezuzah' ${ }^{\prime 6}$ This passage raises two different aspects of domestic devotion. First, Tiktiner suggests that household cleaning had a moral value; second, she mentions the creation of sacred spaces inside the Jewish home. Each will be dealt with in turn.

Let us first look at the religious import that Tiktiner ascribes to cleaning, seen also in a separate passage of the text, in which she discusses women who took on students as boarders:

There are also some [undutiful] cooks who do not fear God, and become angry if a religious book is lying on the table, and say, "I have cleaned up here, and now you are putting books on the table!" But if she puts her children bare-naked on the table and they urinate on it, this filth means nothing to her. It is a great $\sin$, and is a danger to the child. ${ }^{17}$

Not only does Tiktiner advocate keeping a clean house, but she continues by stressing the various religious rewards one is granted for treating Torah scholars with respect: ${ }^{18}$

Even a cook should remember that she too can earn [a place in] Paradise through a young scholar. Her mistress will surely not prevent her from washing his shirt or taking his bedding so it does not become bug-ridden. ${ }^{19}$

The domestic chores of cleaning, cooking, changing the linens of a scholar, and of laundry were rendered as religiously significant by Tiktiner in these passages. These passages are heavily gendered. ${ }^{20}$ Tiktiner stresses that the

16 Tiktiner R., Meneket Rivka: A Manual of Wisdom and Piety for Jewish Women, trans. F. von Rohden (Philadelphia: 2008) 107.

17 Tiktiner, Meneket Rivka 191.

18 Tiktiner, Meneket Rivka 192-193.

19 Tiktiner, Meneket Rivka 189.

20 On the importance of gender and class, see Ulbrich, Shulamit and Margarete; Kaplan D., "Women and Worth: Female Access to Property in Early Modern Urban Jewish Communities", Leo Baeck Institute Year Book 55 (2010) 93-113. 
woman of the house was responsible for cleaning, while the man is mentioned in the context of scholarship. ${ }^{21}$ Here again, we must note the deep similarities between Tiktiner's work and contemporaneous moral literature about Protestant families. In these texts, too, authors urged a gendered division of labour in which women were responsible for specific tasks in the workshop as well as in the domestic sphere. Tiktiner's text similarly encourages a woman to be supportive to her husband, to care for the children, to run a pious household in which charity, hospitality, and children's study took place, and to work. This standard in many ways mirrors what Lyndal Roper has termed the holy household'.22

Hierarchy appears as another important variable in these texts. Even among women, there is a clear gap between the mistress who supervises and the servant who works. For women of both social strata, the home was recognized by Tiktiner as a space in which daily chores took on a devotional purpose. Whether as manager or as laundress, tasks that were considered part of women's daily work could also be linked to devotion.

The connections between women, domestic tasks and religious devotion is similarly portrayed on a small silver box that was likely presented as a gift to an Italian Jewish bride by her bridegroom in the late fifteenth century. The box depicts female performance of the three 'women's commandments'. While Jewish women were obligated to observe many different commandments, three specific commandments were referred to in texts and artwork as 'women's commandments', as they were performed solely by women. ${ }^{23}$ These included lighting candles on the Sabbath, immersing in the mikveh for menstrual purity, and removing a piece of dough when breaking bread. Both classic and contemporary texts prescribe that women to perform these three commandments with utmost care. ${ }^{24}$

The silver box depicts women performing the 'three women's commandments'. From left to right, there is a woman kindling Sabbath candles, a woman immersing in a ritual bath, and a woman separating the requisite dough from her bread [Fig. 15.5]. The blessings recited before performing these

21 This theme is expanded on in Tiktiner, Meneket Rivka 186-187, in the subsection titled 'This will speak of how a woman should supervise her household staff.'

22 Roper, Holy Household.

23 For a scholarly overview of women's obligation to perform various commandments as well as their actual praxis, see Goldin S., Jewish Women in the Middle Ages: A Quiet Revolution (Manchester: 2011) 169-222; see also Baumgarten E., Practicing Piety in Medieval Ashkenaz: Men, Women, and Everyday Religious Observance (Philadelphia: 2014) 138-171.

24 Failure to observe these commandments was linked to dying in childbirth in classical rabbinic literature. See Mishna Tractate Shabbat 2:6. For early modern literature that deals with these three commandments, see Fram E., My Dear Daughter: Rabbi Benjamin Slonik and the Education of Jewish Women in Sixteenth-Century Poland (Cincinnati: 2007). 


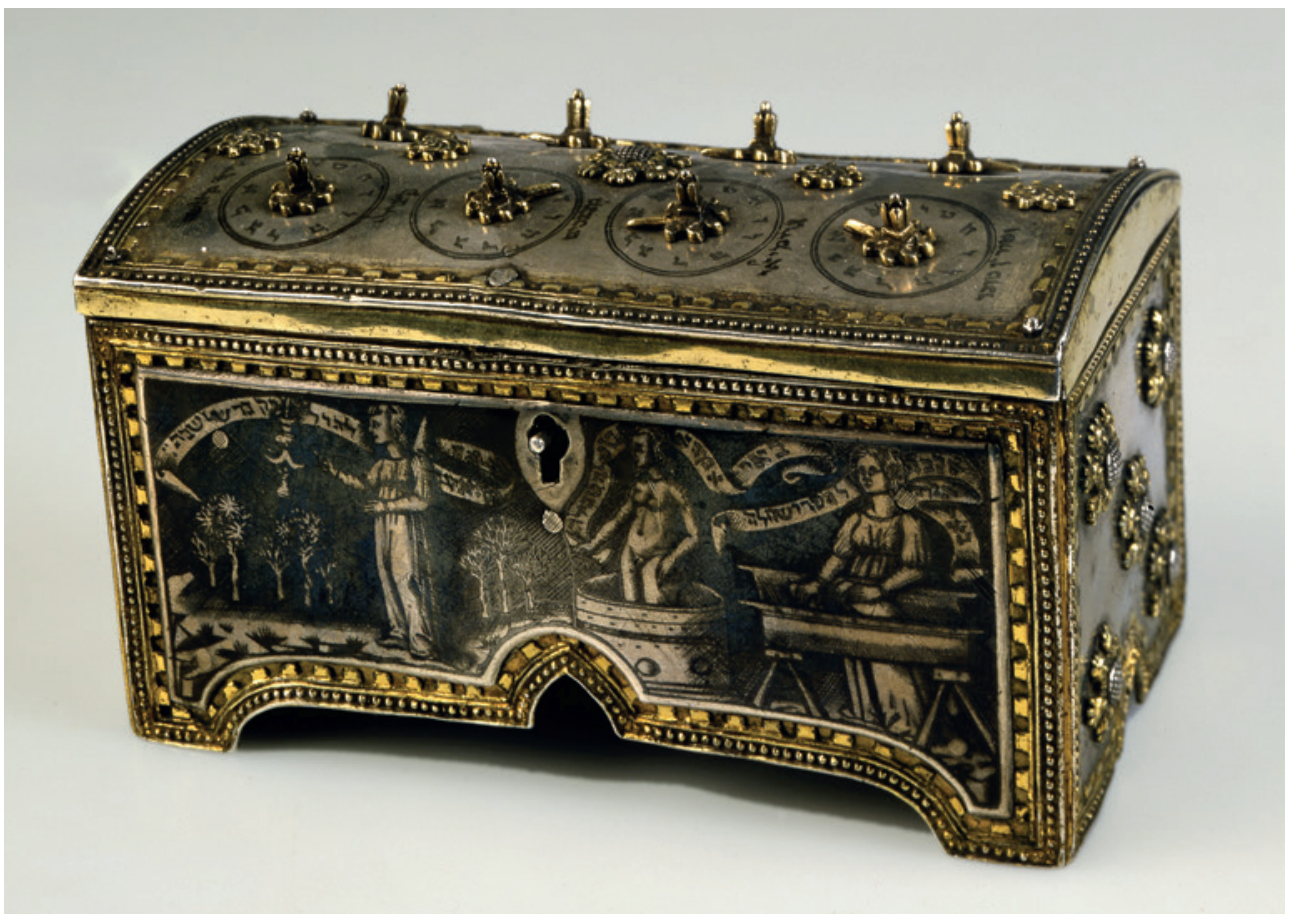

FIGURE 15.5 Bridal casket (cofanetto), Northern Italy (second half of the $15^{\text {th century). Gift }}$ of Astorre Mayer Collection, The Israel Museum, Jerusalem, B51.04.0207 PHOTO (C) THE ISRAEL MUSEUM BY YORAM LEHMANN

commandments are inscribed in Hebrew above the women's heads. Although this is a clearly religious theme, the box itself was likely used for a mundane purpose. The lid of the box has eight knobs or dials. Judeo-Italian words for linens, tablecloths, and sheets are inscribed next to the dials, while around the dials one can see Hebrew letters whose value is equivalent to the numbers one through twelve. This function suggests that the lid of the box permitted the new wife to keep an inventory of linens. ${ }^{25}$ The decision to decorate a woman's household item with a religious theme reiterates the strong connection between domestic life, religious devotion, and women.

Another overlap between women's household tasks and religious devotion was the various occasions on which women brought water into their homes. Jewish popular culture deemed it hazardous to drink water that had been left

25 AvRutick S. (ed.), The Jewish World 365 Days, from the Collections of the Israel Museum (New York: 2004) 426-427. 
out unused during particular liminal times. One such custom was called the tekufah, a practise that restricted using water that had been left out on four specific times throughout the year, during the winter and summer solstices and the autumnal and vernal equinox. ${ }^{26}$ Women were to place a nail in the water, for the iron was deemed to have protective powers; otherwise, they were to ensure that the water was discarded, lest it cause serious illness or death. Similarly, it was customary not to use water that had been left out between the Sabbath and its conclusion after nightfall on Saturday night. Women who discarded that water and who drew new water for their household after the havdalah ceremony were deemed pious like the biblical Miriam. ${ }^{27}$ It was also customary to avoid using water that had been left unused near a corpse. ${ }^{28} \mathrm{In}$ these examples, the practice of drawing water was invested with pious meaning. In these cases, it was the timing of the act that raised it from mundane to pious. In other cases, such as Tiktiner's description of cleaning, women's chores were elevated not through time, but rather through the women's intention to contribute to the scholarship of the men to whom they tended.

Tiktiner's aforementioned reference to cleaning a space 'where one prays, or religious books are, or near the mezuzah' confirms that the space of the home was also used for religious study and prayer. ${ }^{29}$ There are various examples in which a certain space in early modern Jewish homes was designated as a sacred space for the inhabitants of the house. Such spaces were common in the Holy Roman Empire, where the demographic realities of the early modern period required using the home as a place for prayer. During the Middle Ages, the Jews had lived primarily in the large cities along trade routes. From the fourteenth to the seventeenth centuries, however, the Jews were largely expelled

26 Carlebach E., Palaces of Time: Jewish Calendar and Culture in Early Modern Europe (Cambridge MA: 2011) 160-188. On one of the medieval traditions associated with this practice, see Baumgarten E., "'Remember that Glorious Girl': Jephthah's Daughter in Medieval Jewish Culture", Jewish Quarterly Review 97, 2 (2007) 180-209.

27 Shoham-Steiner E., "The Virgin Mary, Miriam, and Jewish Reactions to Marian Devotion in the High Middle Ages", Association for Jewish Studies Review 37, 1 (2013) 75-91.

28 See Schammes, Customs vol. 2, 89. Schammes relates that the neighbours of the dead would pour out all of the water that they had in their respective homes.

29

Tiktiner, Meneket Rivka 107. 
from these urban spaces. ${ }^{30}$ Those Jews that did not migrate elsewhere resided in the countryside, where quotas frequently limited the number of Jews in any one village or town. In Alsace, for example, during the sixteenth and the first half of the seventeenth century, the largest village had only eleven Jewish residents, while most towns had one or two Jewish families. This meant that there was no local synagogue, no rabbi, and that local official communal spaces often did not exist. ${ }^{31}$

The Jews living in these towns and villages used domestic spaces in order to perform rituals that had usually been performed in communal spaces. R. Jehiel Epstein, active in Germany during the mid to late-seventeenth century, recommended that men in German towns who lacked a prayer quorum pray in a designated room. Explaining that in the home's heated main room, family members and other visitors were likely to disturb the prayer, Epstein further suggested that Jewish men cover their heads with a prayer shawl to increase concentration. ${ }^{32}$ Similarly, Asher ha-Levi of Reichshofen, a seventeenthcentury Jew, reports in his memoirs:

The house that I built and I bought with the help of the blessed Lord [...] I built in it three items for myself. The first, a small room to set time aside for Torah [study] and for prayer, and to place in it the books that God had granted me to buy. ${ }^{33}$

By setting aside a particular space in his home as a space for prayer and Torah study, Asher designated that corner as sacred. The placement of books in that room allows us to wonder how that room was decorated, for although the books had a specific use, they also helped demarcate the space as devotional. Designating a section of a home as the area in which prayer was to take place mirrors the contemporaneous use of small Catholic altarpieces and other artwork designed for domestic devotion. While Jews did not use artwork or icons in their devotion, these three texts all reference various physical objects - prayer shawls, books, or mezuzot - as being kept or used in the

$30 \quad$ Toch M., "The Formation of a Diaspora: The Settlement of Jews in the Medieval German Reich", Aschkenas 7 (1997) 55-78.

31 Kaplan D., Beyond Expulsion: Jews, Christians, and Reformation Strasbourg (Stanford: 2011) $27-48$.

32 Epstein Jehiel Michael, Kitzur shenei luhot ha-brit (Berlin, B. Buchbinder: 1715) 68.

33 Asher ha-Levi of Reichshofen, Die Memoiren des Ascher Levy aus Reichshofen im Elsass, ed. M. Ginsburger (Berlin: 1913) 32. Asher also constructed a small oven and a bathhouse. That he considered these structures to be of deep significance reiterates the point, made below, that certain domestic activities were performed outside the home. 
designated sacred spaces. The items had a practical or ritual function but their presence simultaneously demarcated specific areas of the home as sacred.

Tiktiner's reference to a space within the home for prayer and study is somewhat different from the descriptions of Asher and Epstein. Tiktiner's Prague did have synagogues. Yet she, too, refers to spaces within the home that were designated for devotional activities such as study and prayer. Moreover, a comparison of these three authors' references to prayer spaces in the home allows us to consider whether the use of such spaces was gendered. Epstein describes a prayer space in which men used prayer shawls to create sacred spaces. Since prayer shawls were primarily used by men, this space was inherently male. ${ }^{34}$ Tiktiner, by contrast, refers to spaces for prayer and study that were also used by women and children. This is found in a different passage in her book, in which she explained that a woman was responsible for childcare and for children's religious upbringing. She urges:

Therefore every upright woman should remain with her child, and should not go to the synagogue. Just as when she wants to go for a walk, or to sit in front of the door, nothing good can result. But if she sits beside the cradle, she can keep the child asleep, and also do her work. If she is privileged with more children, and they are grown up, she should sit and listen to their praying and their blessings, and not rely on the teacher [...] The studying that a mother does with her child is much more successful than with someone else. ${ }^{35}$

Tiktiner advocated that women stay home to take care of babies, to ensure that older children were praying, studying, and making requisite blessings, and in order to 'do their work'.

The sources do not inform us as to whether the women and children who stayed home and prayed and studied did so in designated areas, such as the one Asher had, or the one Tiktiner urged women to keep clean. We similarly do not know whether the space Asher constructed was used solely by him, or whether his wife and children used that space for prayer and study as well. Yet we do see that in Jewish "holy households", women, men, and children all prayed in the home, whether in designated spaces or in ad hoc locations, even in cases in which there was a local synagogue.

34 Baumgarten, Practicing Piety 149-166.

35 Tiktiner, Meneket Rivka 160-161. 
In some early modern Jewish homes, domestic sacred spaces were not limited to that home's inhabitants, but were sometimes used by a broader range of participants. One such example is the presence of official synagogues in a domicile. This took place in several different Jewish communities throughout the world. ${ }^{36}$ Due to the limited scope of this article, I will present only a few brief examples.

In 1563 , a court case about alleged adultery recounts the presence of a synagogue situated in a home in Hagenau. ${ }^{37}$ Elsewhere in Alsace, Jews from several different towns and villages came together on the Sabbath in one location in order to pray as a quorum. Since the small towns and villages did not have their own synagogues, these prayers typically took place in a home. ${ }^{38}$ This was the case in Traenheim, where local residents were joined by Jews from a neighbouring town, praying on the upper floors of a house. This synagogue remained undetected until recent decades, when the current resident uncovered walls with Jewish prayers when he began renovating his home.

The presence of synagogues in homes was not limited to small villages where no official synagogue existed. In Frankfurt am Main, for example, where the Jews lived in a ghetto, there were two official synagogues. Records from the communal logbook indicate that by the eighteenth century, a number of homes in the ghetto hosted competing prayer services. The existence of these synagogues was reported in the logbooks because the community lay leaders feared that the people who attended services in these smaller domestic spaces would not contribute to the charity collection, which took place in the official synagogues. They therefore instituted set contributions that were expected of those men and women who opted not to pray in the official synagogues, but in the smaller synagogues situated in various homes. ${ }^{39}$

Mikvaot (sing. mikveh), or ritual baths, could also be situated in private homes, although they were used by a wider population. Both men and women could immerse in ritual baths, but according to Jewish law, married Jewish women were expected to immerse a number of days after menstruation in order to return to a state of menstrual purity that would allow them to resume sexual relations with their husbands. In Frankfurt's ghetto, mikvaot were

\footnotetext{
$3^{6}$ For parallels in the Ottoman Empire, see Dotan Arad's essay in this volume.

37 Kaplan, Beyond Expulsion $5^{0}-58$.

38 Haarscher A-M., Les Juifs du Comté de Hanau-Lichtenberg: entre le XIVe siècle et la fin de l'Ancien Régime (Strasbourg: 1997) 74.

39 Fram E., A Window on their World: The Court Diaries of Rabbi Hayyim Gundersheim Frankfurt am Main, 1773-1794 (Cincinnati: 2012) 555-563.
} 
located in the basement of several homes, and some of the archaeological remains can be seen in the Judengasse museum. Similarly, in Altona, two ritual baths in private homes were designated as the official spaces for immersion for the women of Altona and Wandsbeck in $1681 .{ }^{40}$ In that year, and for four subsequent years, the leaders of the community decreed that any woman who immersed elsewhere was considered as having not immersed at all. This decree had serious religious implications, as the leaders decreed that despite immersion elsewhere, such a woman was still considered in a state of menstrual impurity, which rendered sexual relations with her husband forbidden.

The designation of a space within a home as a communal ritual bath led to the enactment of multiple regulations to govern the space. An intricate arrangement in which the women living in the two houses with mikvaot were appointed to oversee women's immersion was developed. As official attendants, they were tasked both with collecting fees for immersion and for ensuring that women immersed completely and properly in the ritual bath. ${ }^{41}$ The two families in whose homes the mikvaot were located were compensated for their work and expenses. This underscores how work, devotion, and the home were categories that frequently overlapped. By building a communal space in a home, the home's residents performed an official communal duty - one they likely experienced as religiously significant - though they were compensated for this work. Local women were to pay a fixed fee for immersing, the proceeds of which were divided between the community and the head of household at a pre-determined rate. These homes, therefore, generated revenue for the community and for the heads of household. As the only officially-sanctioned ritual baths, these spaces served as communal institutions despite their location in private homes. ${ }^{42}$

\section{Defining the Domestic Sphere}

The considerable overlap between home and communal spaces does not allow for a simple treatment of domestic devotion, for homes could include a communal institution. The inverse was also true in that domestic tasks were sometimes performed outside of the home. To illustrate this point, I will return to

$40 \quad$ Kaplan D., “'To Immerse their Wives': Communal Identity and the 'Kahalishe' Mikveh of Altona", Association for Jewish Studies Review 36, 2 (2012) 257-279.

41 In the Middle Ages, though a woman immersed in the company of another woman, there was no formal attendant. See Kaplan, "To Immerse" 260.

42 See Kaplan, "To Immerse" $268-269$, on changes that revoked the status of these ritual baths in 1685 . 
the three aforementioned 'women's commandments'. All three of these commandments revolve around what may be considered domestic activities: lighting candles in the home, baking, and resuming sexual relations. Nevertheless, their domestic nature did not mean that they were performed in the space of the home. While, as we have seen, candle lighting took place in the home, women immersed in a communal ritual bath that could be situated either in or outside of a home. Certainly, most women immersed outside of their own homes. ${ }^{43}$ As was mentioned above, the early modern period witnessed the establishment of official communal ritual baths. In 1597 in Padua, for example, the communal leaders decreed that women were to immerse in the official ritual bath, under penalty of a fine. ${ }^{44}$ Moreover, as in the somewhat later aforementioned case in Altona, the lay leaders in Padua ruled that any woman who immersed elsewhere would be considered as if she had not immersed; all sexual relations with her husband thereafter would be deemed forbidden. However, in 1613, a case was brought before the community's leaders. The wife of Rabbi Judah Napoli, who is unnamed in the text, was loath to immerse in the communal mikveh due to a feud between her family and that of the official attendant who governed the mikveh. The lay leaders made an exception for this woman, and allowed her to immerse elsewhere. ${ }^{45}$ This anecdote highlights that immersion was far from private. First, immersion was regulated by male communal leaders. Moreover, although immersion was a female activity that revolved around sexual intimacy and marriage, it was performed in a space that was neither private nor public. Immersion was a domestic devotion performed outside of the home. Women's experiences during immersion were shaped both by the location of the ritual bath and by the specific people who were present in that space, such as the attendant.

Baking bread, another domestic task, was also not necessarily performed in the home, since not every home had an oven. In medieval communities, when bread was not baked at home, it was baked either in a communal oven or in a Christian bakery. ${ }^{46}$ Various controversies that respectively arose in Frankfurt am Main, Mainz, and Worms during the eighteenth century document that in

43 Medieval Worms and Speyer had communal bathhouses, still visible today. By the early modern period, many communities required that women immerse in the communal mikveh. See Kaplan, "To Immerse" 272-273.

Minutes Book of the Council of the Jewish Community of Padua 1577-1603, ed. D. Carpi (Jerusalem: 1973) 348.

45 Minutes Book $15^{8-159 .}$

46 Strauss D.L., Pat 'Akum in Medieval France and Germany, M.A. thesis (Yeshiva University: 1979). 
early modern times, Jews often bought bread from Christian bakers. ${ }^{47}$ Although the task of baking was typically defined domestic, it was often practised by men and women outside the home.

Early modern domestic devotion was a fluid category that took on several forms. Certain rituals were designed to be performed at home. Domestic chores, and other work that was performed in the home could take on religious meaning, particularly for women. Sections of one's home could be transformed into a space for religious activity, whether for its inhabitants or for the wider community. In those homes in which communal spaces were situated, residents often laboured in the official communal space in their homes, such that their actions were simultaneously domestic, devotional, and work-related. Some domestic tasks, including those with ritual aspects, were performed outside the home. This complex interplay between spaces, work, domestic life, family, and religion, which was common among both Jews and Christians, reflects the multiple functions of the early modern home and the centrality of religious expression to early modern daily life.

\section{Bibliography}

Asher ha-Levi, Die Memoiren des Ascher Levy aus Reichshofen im Elsass, M. Ginsburger (ed.) (Berlin: 1913).

AvRutick S. (ed.), The Jewish World ${ }_{3} 65$ Days, from the Collections of the Israel Museum (New York: 2004) 426-427.

Baumgarten E., Mothers and Children:Jewish Family Life in Medieval Europe (Princeton: 2004).

Baumgarten E., "Remember that Glorious Girl': Jephthah's Daughter in Medieval Jewish Culture", Jewish Quarterly Review 97, 2 (2007) 180-20.

Baumgarten E., Practicing Piety in Medieval Ashkenaz: Men, Women, and Everyday Religious Observance (Philadelphia: 2014).

Baumgarten J., "Prayer, Ritual, and Practice in Ashkenazic Jewish Society: The Tradition of Yiddish Custom Books in the Fifteenth through Eighteenth Centuries", Studia Rosenthaliana 36 (2002-3) 121-46.

47 On Frankfurt, see Schudt Jacob Johann, Jüdische Merckwürdigkeiten (Frankfurt, S.T. Hocker: 1714) vol. 1, 68; on Mainz, see Litt S., "Rabbinic Authority and Community in 18th Century Germany: Moses Brandeis Levi and the Jewish Community of Mainz", http://wesscholar.wesleyan.edu/emw/emw2010/emw2010/7/. On Worms, see Stadtarchiv Worms, $1 \mathrm{~B} 2034$. 
Berkovitz J.R., "Jewish Philanthropy in Early Modern and Modern Europe: Theory and Practice in Historical Perspective", in Prager Y. (ed.), Toward a Renewed Ethic of Jewish Philanthropy (New York: 2010).

Bock G., "Challenging Dichotomies: Perspectives on Women's History", in Offen K. Pierson R.R. - Rendall J. (eds.), Writing Women's History: International Perspectives (London: 1991) 1-23.

Carpi D. (ed.), Minutes Book of the Council of the Jewish Community of Padua 1577-1603, (Jerusalem: 1973).

Carlebach E., Palaces of Time: Jewish Calendar and Culture in Early Modern Europe (Cambridge, Mass.: 2011).

Epstein Jehiel Michal ben Abraham, Kitzur Shelah (Frankfurt a.M., B. Buchbider: 1715). Feuchtwanger-Sarid N., "How Italian are the Venice 'Minhagim' of 1593? A Chapter in the History of Yiddish Printing in Italy", in Graetz M. (ed.), Schöpferische Momente des europäischen Judentums in der frühen Neuzeit (Hamburg: 2000) 177-205.

Fram E., My Dear Daughter: Rabbi Benjamin Slonik and the Education of Jewish Women in Sixteenth-Century Poland (Cincinnati: 2007).

Goldin S., Jewish Women in the Middle Ages: A Quiet Revolution (Manchester: 2011).

Gray A., "Married Women and Tsedaqah in Medieval Jewish Law: Gender and the Discourse of Legal Obligation", Jewish Law Association Studies 18 (2007) 168-212.

Haarscher A.-M., Les Juifs du Comté de Hanau-Lichtenberg: entre le XIVe siècle et la fin de l'Ancien Régime (Strasbourg: 1997).

Hsia R. Po-Chia, "Christian Ethnographies of Jews in Early Modern Germany", in Waddington R.B. - Williamson A.H. (eds.), The Expulsion of the Jews, 1492 and After (New York: 1994) 223-235.

Kaplan D., "Women and Worth: Female Access to Property in Early Modern Urban Jewish Communities”, Leo Baeck Institute Year Book 55 (2010) 93-113.

Kaplan D., Beyond Expulsion: Jews, Christians, and Reformation Strasbourg (Stanford: 2011).

Kaplan D., “To Immerse their Wives': Communal Identity and the 'Kahalishe' Mikveh of Altona", AJs Review 36, 2 (2012) 257-279.

Kosman Joseph, Noheg ka-tzon Yosef (Hanau, Jacob Bassange: 1718).

Levine-Melammed R., Heretics or Daughters of Israel? The Crypto-Jewish Women of Castile (Oxford: 2002).

Litt S., "Rabbinic Authority and Community in 18th Century Germany: Moses Brandeis Levi and the Jewish Community of Mainz", http://wesscholar.wesleyan.edu/emw/ emw2010/emw2010/7.

Roper L., The Holy Household: Women and Morals in Reformation Augsburg (Oxford: 1989).

Sabar S., "Childbirth and Magic: Jewish Folklore and Material Culture", in Biale D. (ed.), Cultures of the Jews: A New History (New York: 2002) 671-722. 
Schammes J., Customs of the Holy Community of Worms, Hamburger B.S. - Zimmer E. (eds.), 2 vols. (Jerusalem: 1988).

Schudt Jacob Johann, Jüdische Merckwürdigkeiten (Frankfurt, S.T. Hocker: 1714).

Shoham-Steiner E., "The Virgin Mary, Miriam, and Jewish Reactions to Marian Devotion in the High Middle Ages", AJs Review 37, 1 (2013) 75-91.

Slonik Benjamin, She'elot u-teshuvot masa'at Binyamin (Krakow, Meisels: 1632).

Strauss D.L., Pat 'Akum in Medieval France and Germany, M.A. thesis (Yeshiva University: 1979).

Tiktiner R., Meneket Rivka: A Manual of Wisdom and Piety for Jewish Women, trans. F. von Rohden (Philadelphia: 2008).

Toch M., "The Formation of a Diaspora:The Settlement of Jews in the Medieval German Reich", Aschkenas 7 (1997) 55-78.

Ulbrich C., Shulamit and Margarete: Power, Gender, and Religion in a Rural Society in Eighteenth-Century Europe, trans. T. Dunlap (Leiden: 2004).

Wunder H., He is the Sun: She is the Moon: Women in Early Modern Germany, trans. T. Dunlap (Cambridge, Mass.: 1998). 